\title{
Analysis of Weld Line Influence on Strength of Nylon Parts
}

Karel Raz, Martin Zahalka, Zdenek Chval, Ludmila Kucerova

Regional Technological Institute, Faculty of Mechanical Engineering, University of West Bohemia. Univerzitni 8, 306 14 Plzen.Czech Republic.E-mail: kraz@rti.zcu.cz, martinza@rti.zcu.cz, zdchval@rti.zcu.cz, skal@kmm.zcu.cz

Main aim of this article is description of weld line influence on mechanical properties of plastic parts. Special design of mold was created for this research. This mold is able to create specimens with and without weld lines. These specimens undergone tensile test according standard ASTM D638 with different results. Strength and strain results were compared for both types of specimens. Nylon PA6 without any internal reinforcement was used as reference material during testing. Both specimens were investigated also by microscope in order to see composition of weld line and plastic material. Microstructure showed geometry of weld line and also fracture surfaces indicated presence of plastic deformation

Keywords: Weld Line, Strain, Tensile Test, Nylon

\section{Acknowledgments}

The present contribution has been prepared under project LO1502 'Development of the Regional Technological Institute' under the auspices of the National Sustainability Programme I of the Ministry of Education of the Czech Republic aimed to support research, experimental development and innovation.

\section{References}

[1] ZHENG, R., TANNER, R., FAN, X. (2011). Injection Molding: Integration of Theory and Modeling Methods, Springer-Verlag, Berlin.

[2] BOZZELLI, J. (2010). Understanding Pressure Loss in Injection Molding, In: Plastic Technology.

[3] TANG, S.H. (2006). Design and thermal analysis of plastic injection mold, In: Journal of Materials Processing Technology. Switzerland.

[4] COP. J., FOJTL, L., BILEK, O., PATA, V. (2016). Influence of Finishing Operations and Melt Flow Index on Surface Quality of Injection Molded Parts, In: Manufacturing Technology, Vol. 16, pp. 336-338, ISSN 12132489.

[5] HNATKOVA, E., SANETRIK, D., PATA, V., HAUSNEROVA, B., DVORAK, Z. (2016). Mold Surface Analysis after Injection Molding of Highly Filled Polymeric Compounds, In: Manufacturing Technology, Vol. 16, pp. 86-90, ISSN 1213-2489.

[6] MARKOVICOVA, L., ZATKALIKOVA, V. (2016). Composite Materials Based on pa Reinforced Glass Fibers, In: Materials Today: Proceedings, Vol. 3, pp. 1056-1059, E-ISSN:2214-7853

[7] RUSNAKOVA, S., CAPKA, A., FOJTL, L., ZALUDEK, M., RUSNAK, V. (2016). Technology and Mold Design for Production of Hollow Carbon Composite Parts, In: Manufacturing Technology, Vol. 16, pp. 799-804, ISSN 1213-2489.

[8] FABIAN, M., BOSLAI, R., IZOL. P., JANEKOVA, J., FABIANOVA, J., FEDORKO, G., BOZEK, P. (2015). Use of Parametric 3D Modeling. Tying Parameter Values to Spreadsheets at Designing Molds for Plastic Injection, In: Manufacturing Technology, Vol. 16, pp. 24-31, ISSN 1213-2489.

[9] NHUYEN VO, T., SEIDL, M. (2016). Evaluation of Applicability of Unconventional Cooling Method in Injection Mould, In: Manufacturing Technology, Vol. 16, pp. 220-225, ISSN 1213-2489. 